Janoskova, K., \& Kral, P. (2019). An In-Depth Analysis of the Summary Innovation Index in the V4

Countries. Journal of Competitiveness, 11(2), 68-83. https://doi.org/10.7441/joc.2019.02.05

\title{
AN IN-DEPTH ANALYSIS OF THE SUMMARY INNOVATION INDEX IN THE V4 COUNTRIES
}

\section{- Katarina Janoskova, Pavol Kral}

\begin{abstract}
Innovative activity is an important source of competitiveness, economic growth, as well as the image of each country. There are several ways to measure and evaluate the innovation performance of a country. Our research was focused on the summary innovation index (SII), a tool used for analysing the innovative ability of European countries. The Innovation Union is an EU initiative which monitors progress achieved in research, development, and innovation, all indicators which are included in the SII. The aim of this paper is to analyse the impact of all SII 27 indicators, which are divided into 10 main areas: human resources, research systems, innovation-friendly environment, finance and support, firm investments, innovators, linkages, intellectual assets, employment impacts, sales impacts. All these indicators are considered in creating the total value of the SII. A statistically significant relationship was determined among all the SII indicators and the total value of the SII using samples from the V4 countries of Czech Republic, Slovakia, Hungary, and Poland during the period 2010-2016. The aim of the research was to identify possible strengths and weaknesses of the national innovation systems of these countries and, thus to identify the impact of these strengths and weaknesses on the innovative position of these countries.
\end{abstract}

Keywords: innovation, summary innovation index, V4 countries, competitiveness, regression analysis JEL Classification: 030

Received: September, 2018

1st Revision: April, 2019

Accepted: May, 2019

\section{INTRODUCTION}

Innovations play an inevitable part in continued economic growth (Misankova \& Chlebikova, 2013), improving the standard of living (Hraskova, 2012) and the development of society. The modern knowledge-based economy (Wierzbicka, 2018) as well as innovations are an essential part of this modern system. Innovative activity is perceived to be a source of competitiveness and economic growth. New products, utility models, trademarks and creative projects are an important element of the present socio-economic reality (Roszko-Wojtowicz \& Bialek, 2016). Innovations are generally considered an accelerator of the economy (Paliderova \& Hraskova, 2016). Innovation performance varies from one company to another and from one country to another, influenced by a variety of factors (Sipos et al., 2014; Nica et al., 2017; Popescu, 2017; Popp et al., 
2018; Regnerova \& Regnerova, 2017). It is quite difficult to measure the innovative activity of a country, which consists of several different areas that affect the innovation performance. Two well-known ways to measure and evaluate the innovation performance of a country are global innovation index (GII) and summary innovation index (SII). Albulescu \& Draghici (2016) have used both of these indices to measure the entrepreneurial activity and national innovate capacity of selected European countries. Our research focuses on the summary innovation index (SII) only, with the aim of analzying the impact of 27 SII indicators, which are divided into 10 main areas: human resources, research systems, innovation-friendly environment, finance and support, firm investments, innovators, linkages, intellectual assets, employment impacts, sales impacts, with these areas comprising the total value of the SII. The research was carried out using samples from the Visegrad Group countries Slovakia, Czech Republic, Poland and Hungary for the period 2010-2016.

The first part of the paper provides a brief overview of the scientific literature, describing the SII as an important measurement tool for the innovative activity of a country. The second section of the paper presents the research methodology, with our calculations done using the IBM SPSS Statistics v. 19 for Windows and MS Excel. The following parts present the main research results together with a discussion of the strengths and weaknesses of the research, with the last part then summarizing the most significant research outcomes.

\section{THEORETICAL BACKGROUND}

Taking into consideration the positive impact of innovation, the European Commission outlined the most common strategies for EU countries to promote innovative activities at the European level to achieve the performance recorded in this area by the United States and Japan. Hence, an aggregate indicator of innovation, the SII, was created to allow the measurement of the level of innovation performance, with the ultimate goal of adopting effective strategies for the purposes of intensifying the influence of EU nations at the macroeconomic level (Stoian \& Nica, 2016; Bavec, 2009; Kyzenko et al., 2017; Mece, 2017; Moravcikova et al., 2017).

The SII is used for analyzing the level of innovative ability of European countries. As an EU initiative, the Innovation Union monitors and periodically reports on the progress achieved in research, development, and innovations. Comparative tables analysing key indicators are compiled to help to assess progress in this area (Oslikova et al., 2015; Cygler \& Sroka, 2017; Fanelli \& Ryden, 2018; Gorb, 2017; Kasych \& Vochozka; 2017). Our research, which focused only on EU countries, used a summary innovation index consisting of 27 indicators divided into 10 categories: human resources, research systems, innovation-friendly environment, finance and support, firm investments, innovators, linkages, intellectual assets, employment impact and sales impact. (Sadaf et al., 2018; Stonkute et al., 2018; Vojtovic, 2016)

Many authors have utilized the summary innovation index in their researches on innovation issues. In their research, Svagzdiene \& Kuklyte (2016) have dealt with the factors affecting the changes in summary innovation index for chosen EU countries. Scholleova (2009) applied the SII to evaluate the national innovation system of the Czech Republic. Rylkova (2016) also evaluated the innovation performance of the Czech Republic using an international benchmark based 
on the SII 2014. Mikolajczyk (2015) has analyzed the level of innovativeness of Poland compared to other EU countries using the SII; Ostraszewska \& Tylec (2016) dealt with the innovation performance of Poland focusing on research \& development. Fabova \& Janakova (2015) have focused on the insufficient innovation performance of the Slovak Republic as the main reason for its low competitiveness. Sipos et al. (2014) have analyzed the correlation among the proportion of innovative companies across countries in their research; here the lack of information on markets is a highly significant factor that hampered innovation activities as shown in SII 2012. Majerova (2015) used the SII to measure the innovativeness of European economies, dealing with interactions between competitiveness and innovation in selected EU countries and Switzerland. (Kliestik et al., 2018; Kliestikova et al., 2017; Lazaroiu \& Rommer, 2017). Zelazny \& Pietrucha (2017) applied databases of innovation indicators (Innovation Union Scoreboard Database) as variables for an empirical meta-analysis. Zygmunt (2017) focused only on the innovation activities of Polish firms in research based on a multivariate analysis of moderate innovator countries.

\section{RESEARCH OBJECTIVE AND METHODOLOGY}

Our research is based on an analysis of secondary information about the SII values along with their indicators and dimensions during the period 2010 - 2016. The SII is a composite indicator that measures the innovation performance of a country. It reflects the average performance considering all the individual indicators. Based on their average performance scores as calculated by the SII, each member state falls into one of four performance groups:

- innovation leaders showed a performance of at least $20 \%$ above that of the EU28,

- strong innovators showed a performance of between $10 \%$ below and $20 \%$ above that of the EU28,

- moderate innovators showed a performance of between $10 \%$ to $50 \%$ below the EU28 performance,

- modest innovators showed a performance of $50 \%$ of that of the EU28.

Our research focuses on the innovation performance of the four countries of the Visegrad group, i.e. Slovakia, Czech Republic, Poland, and Hungary. The performance values of these four countries are compared with the average performance values of all EU countries.

The aim of this paper is to analyze the impact of the SII indicators on the total value of the SII. The indicators are listed in the following table (Tab. 1).

Tab. 1 - Indicators and Abbreviations. Source: own processing according to the European Innovation Scoreboard

\begin{tabular}{|l|c|l|c|}
\hline Name of indicator & Abbr. & Name of indicator & Abbr. \\
\hline New doctorate graduates & $\mathrm{X}_{1}$ & $\begin{array}{l}\text { SMEs with marketing/organiza- } \\
\text { tional innovation }\end{array}$ & $\mathrm{X} 15$ \\
\hline
\end{tabular}




\begin{tabular}{|c|c|c|c|}
\hline $\begin{array}{l}\text { Population completed tertiary } \\
\text { education }\end{array}$ & $\mathrm{X}_{2}$ & SMEs innovating in-house & $\mathrm{X}_{16}$ \\
\hline Lifelong learning & $\mathrm{X}_{3}$ & $\begin{array}{l}\text { Innovative SMEs collaborating with } \\
\text { others }\end{array}$ & $\mathrm{X}_{17}$ \\
\hline $\begin{array}{l}\text { International scientific co-publica- } \\
\text { tions }\end{array}$ & $\mathrm{X}_{4}$ & Public-private co-publications & $\mathrm{X}_{18}$ \\
\hline $\begin{array}{l}\text { Scientific publications among top } 10 \\
\% \text { most cited }\end{array}$ & $\mathrm{X}_{5}$ & $\begin{array}{l}\text { Private co-funding of public R\&D } \\
\text { expenditures }\end{array}$ & $\mathrm{X}_{19}$ \\
\hline Foreign doctorate students & $\mathrm{X}_{6}$ & PCT patent applications & $\mathrm{X}_{20}$ \\
\hline Broadband penetration & $\mathrm{X}_{7}$ & Trademark applications & $\mathrm{X}_{21}$ \\
\hline $\begin{array}{l}\text { Opportunity-driven entrepreneur- } \\
\text { ship }\end{array}$ & $\mathrm{X}_{8}$ & Design applications & $\mathrm{X}_{22}$ \\
\hline Public R\&D expenditure & $\mathrm{X}_{9}$ & $\begin{array}{l}\text { Employment in knowledge-intensive } \\
\text { activities }\end{array}$ & $\mathrm{X}_{23}$ \\
\hline Venture capital & $\mathrm{X}_{10}$ & $\begin{array}{l}\text { Employment in fast-growing firms } \\
\text { of innovative sectors }\end{array}$ & $\mathrm{X}_{24}$ \\
\hline Business R\&D expenditure & $\mathrm{X}_{11}$ & $\begin{array}{l}\text { Medium \& high tech product } \\
\text { exports }\end{array}$ & $\mathrm{X}_{25}$ \\
\hline Non-R\&D innovation expenditure & $\mathrm{X}_{12}$ & $\begin{array}{l}\text { Knowledge-intensive services } \\
\text { exports }\end{array}$ & $\mathrm{X}_{26}$ \\
\hline Enterprises providing ICT training & $\mathrm{X}_{13}$ & $\begin{array}{l}\text { Sales of new-to-market and new-to- } \\
\text { firm innovations }\end{array}$ & $\mathrm{X}_{27}$ \\
\hline $\begin{array}{l}\text { SMEs with the product or process } \\
\text { innovations }\end{array}$ & $\mathrm{X}_{14}$ & & \\
\hline
\end{tabular}

The indicators are divided into 10 categories:

- Human resources $\left(\mathrm{X}_{1}-\mathrm{X}_{3}\right)$

- Research systems $\left(\mathrm{X}_{4}-\mathrm{X}_{6}\right)$

- Innovation-friendly environment $\left(\mathrm{X}_{7}-\mathrm{X}_{8}\right)$

- Finance \& support $\left(\mathrm{X}_{9}-\mathrm{X}_{10}\right)$

- Firm investments $\left(\mathrm{X}_{11}-\mathrm{X}_{13}\right)$

- Innovators $\left(\mathrm{X}_{14}-\mathrm{X}_{16}\right)$

- Linkages $\left(\mathrm{X}_{17}-\mathrm{X}_{19}\right)$

- Intellectual assets $\left(\mathrm{X}_{20}-\mathrm{X}_{22}\right)$

- Employment impacts $\left(\mathrm{X}_{23}-\mathrm{X}_{24}\right)$

- Sales impacts $\left(\mathrm{X}_{25}-\mathrm{X}_{27}\right)$

The research is divided into several steps:

1. Evaluation of the SII's trends in selected monitored countries and a subsequent comparison with the EU average (MS Excel). 
2. Identification of the indicators with the greatest impact on the SII value using a correlation analysis (IBM SPSS Statistics v. 19 for Windows).

3. Identification of the main predictors explaining the SII trends using a regression analysis (IBM SPSS Statistics v. 19 for Windows).

\section{RESULTS}

The first part of the research is an evaluation of the SII's trends in the V4 countries and the comparison with the EU average. The SII values are given for the period $2010-2016$ and are shown in the following chart (Fig. 1).

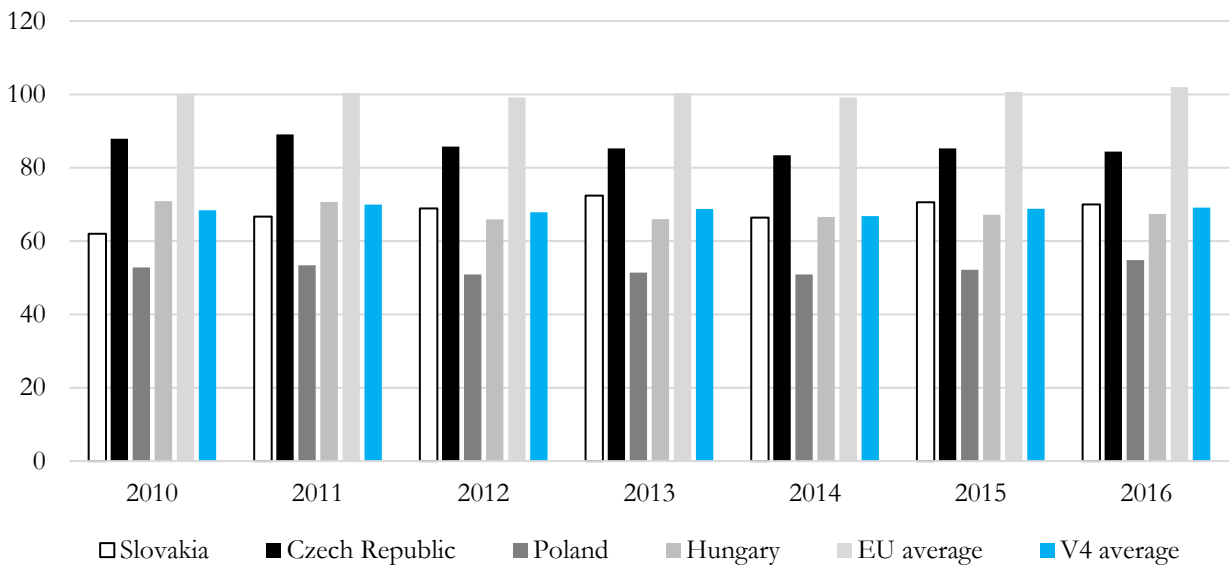

Fig. 1 - Summary Innovation Index 2010 - 2016. Source: own processing according to the European Innovation Scoreboard

Slovakia belongs to the moderate innovators. During the reporting period, the Slovak Republic had the performance between $28 \%$ and $38 \%$ below the EU28 performance. Slovakia is one of the seven countries, whose performance improved by $5 \%$ or more. In the case of Slovakia, the performance increased strongly until 2013 but declined between 2013 and 2016. The performance of Slovakia increased by $8.0 \%$ relative to that of the EU in 2010. Relative strengths of the innovation system of the Slovak Republic are identified in the following categories: employment impacts, sales impacts, and human resources. Relative weaknesses are found in the categories: innovators, intellectual assets, and attractive research systems.

The Czech Republic also belongs to the moderate innovators. During the reporting period, the Czech Republic had the performance between $11 \%$ and $17 \%$ below the EU28 performance. The Czech Republic is one of the ten countries, whose performance declined by up to $5 \%$. Moreover, in the case of the Czech Republic, the annual performance was changing at relatively moderate rates, with a stronger decline reported in 2012. The performance declined by $3.5 \%$ over time relative to that of the EU in 2010. Relative strengths of the Czech Republic innovation system are 
identified in the following categories: firm investments, employment impacts, and sales impacts. Relative weaknesses are found in the categories: intellectual assets, linkages, and innovators.

Poland belongs to the moderate innovator as well. During the reporting period, Poland had the performance between $45 \%$ and $49 \%$ below the EU28 performance. Poland is one of the eight countries, whose performance improved by less than $5 \%$. The performance increased by $2.0 \%$ over time relative to that of the EU in 2010. Relative strengths of the innovation system of Poland are identified in the following categories: employment impact, firm investments, an innovation-friendly environment. Relative weaknesses are found in the categories: innovators, linkages, and attractive research systems.

Hungary is also the moderate innovator. During the reporting period, Hungary had the performance between $29 \%$ and $34 \%$ below the EU28 performance. Hungary is one of the ten countries, whose performance declined by up to $5 \%$. In the case of Hungary, the performance declined until 2013 was followed by a performance increase between 2013 and 2016. The performance declined by $3.5 \%$ over time relative to that of the EU in 2010. Relative strengths of the innovation system of Hungary are identified in the following categories: employment impacts, sales impacts, an innovation-friendly environment. Relative weaknesses are found in the categories: innovators, finance and support, and intellectual assets.

To sum it up, the Czech Republic has the best position whereas Poland has the worst position. Slovakia and Hungary have about the same level of performance. The comparison of individual categories of the SII (2016) is given in the following chart (Fig. 2).

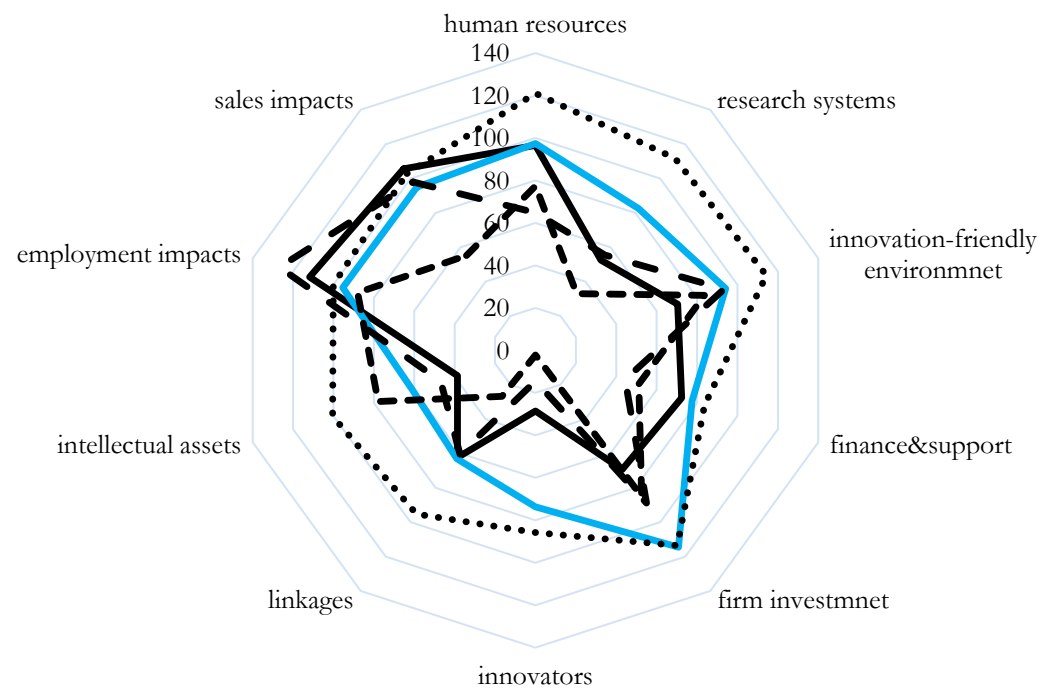

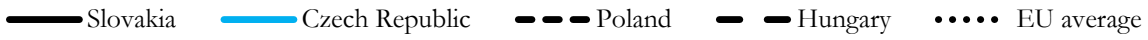

Fig. 2 - SII Dimensions in 2016. Source: own processing according to the European Innovation Scoreboard 
The second part of the research is the identification of indicators that have the greatest impact on the value of the SII using correlation analysis. The indicators with a strong positive or negative correlation with the SII value during the period 2010 - 2016 are given in the following table (Tab. 2). The table contains only the indicators with the Pearson correlation coefficient value higher than 0.7 and with a p-value lower than the significance level of 0.05 .

Tab. 2 - Indicators with a strong impact on the SII. Source: own processing

\begin{tabular}{|c|c|c|c|c|c|c|c|c|c|c|c|c|c|c|c|c|c|c|c|c|c|c|c|c|c|c|c|}
\hline \multicolumn{28}{|c|}{ Indicators SII } \\
\hline & 1 & 2 & 3 & 4 & 5 & 6 & 7 & 8 & 9 & 10 & ${ }_{11}$ & 12 & 13 & 14 & 15 & 16 & 17 & 18 & 19 & 20 & 21 & 22 & 23 & 24 & 25 & 26 & 27 \\
\hline SK & & & $\checkmark$ & & & & & & & & & & & & & & & & & $\checkmark$ & & & $\checkmark$ & & & & $r$ \\
\hline $\mathrm{CZ}$ & $\checkmark$ & $\checkmark$ & & $\checkmark$ & & $\checkmark$ & & $\checkmark$ & $\checkmark$ & $\checkmark$ & $\checkmark$ & & & $\checkmark$ & $\checkmark$ & $\checkmark$ & & & & & & & & & & $\checkmark$ & r \\
\hline P L & & & & & & & & & & $\checkmark$ & & $\checkmark$ & & & & & & & & & & & & & & $\checkmark$ & \\
\hline $\mathrm{HU}$ & & $\checkmark$ & & & & & & & & & & & & $\checkmark$ & & $\checkmark$ & & & & & & $\checkmark$ & & & $\checkmark$ & & \\
\hline $\mathrm{EU}$ & & & & & & & $r$ & & & & & & & & & & & $\checkmark$ & & & & $\checkmark$ & & & $\checkmark$ & $\checkmark$ & \\
\hline
\end{tabular}

In the case of Slovakia, the indicators with a strong positive correlation are PCT patent applications ( $\mathrm{r}=0.828$; sig. 0.021), and Sales of new-to-market and new-to-firm innovations $(\mathrm{r}=0.795$; sig. 0.033$)$. The indicators with a strong negative correlation are Lifelong learning $(\mathrm{r}=-0.755$; sig. 0.050), and Employment in knowledge intensive activities ( $r=-0.799$; sig. 0.031).

In the case of the Czech Republic, the indicators with a strong positive correlation are Venture capital ( $r=0.791$; sig. 0.034), SMEs with product or process innovations ( $r=0.887$; sig. 0.008), SMEs with marketing and organizational innovations ( $\mathrm{r}=0.828$; sig. 0.022), SMEs innovating in-house ( $r=0.842$; sig. 0.018), and Sales of new-to-market and new-to-firm innovations ( $r=$ 0.929; sig. 0.003). The indicators with a strong negative correlation are New doctorate graduates $(\mathrm{r}=-0.851$; sig. 0.015), Population completed tertiary education $(\mathrm{r}=-0.759$; sig. 0.048), International scientific co-publications $(r=-0.795$; sig. 0.033), Foreign doctorate students $(r=-0.758$; sig. 0.049), Opportunity driven entrepreneurship ( $\mathrm{r}=-0.819$; sig. 0.024), Public R\&D expenditure ( $r=-0.929$; sig. 0.002), Business R\&D expenditure ( $r=-0.852$; sig. 0.015), and Knowledge intensive services exports $(\mathrm{r}=-0.923$; sig. 0.003).

In the case of Poland, the indicators with a strong positive correlation are Non-R\&D expenditures $(\mathrm{r}=0.851$; sig. 0.015), and Knowledge intensive services exports $(\mathrm{r}=0.782$; sig. 0.038). The indicator with a strong negative correlation is Venture capital $(\mathrm{r}=-0.849$; sig. 0.016).

In the case of Hungary, the indicators with a strong positive correlation are SMEs with product or process innovations ( $r=0.774$; sig. 0.041), SMEs innovating in-house ( $r=0.905$; sig. 0.005), Design applications ( $r=0.932$; sig. 0.002), and Medium \& high tech product exports $(r=0.854$; sig. 0.014). The indicator with a strong negative correlation is Population completed tertiary education ( $r=-0.873$; sig. 0.010).

In the case of the EU28, the indicators with a strong positive correlation are Broadband penetration ( $r=0.865$; sig. 0.012), Knowledge intensive services exports ( $r=0.805$; sig. 0.029), and Medium \& high tech product exports $(\mathrm{r}=0.824$; sig. 0.023$)$. The indicators with a negative cor- 
relation are Public-private co-publications ( $\mathrm{r}=-0.848$; sig. 0.016), and Design applications ( $\mathrm{r}=$ -0.779; sig. 0.039).

We can see many departures in the key indicators with a positive or negative correlation with the SII value in monitored countries.

The third part of the research is the identification of main predictors explaining the SII trends using a regression analysis.

\section{Slovakia}

In the case of Slovakia, three models were created in the first phase of regression modeling. The first model contained one predictor $\left(\mathrm{X}_{20}\right)$, the second model contained two predictors $\left(\mathrm{X}_{20}, \mathrm{X} 10\right)$, and the third model contained three predictors $\left(\mathrm{X}_{20}, \mathrm{X}_{10}, \mathrm{X}_{9}\right)$. The second and the third model were excluded because the predictors (indicators) $\mathrm{X}_{10}$ and $\mathrm{X}_{9}$ had a low correlation with the SII.

Basic data about the regression model are summarized in the following table (Tab. 3). The coefficient of determination, $\mathrm{R}^{2}$, is an important statistical measure that gives more information about the goodness of fit of a model as well as how well the regression predictions approximate the real data points. The $\mathrm{R}^{2}$ of 1 indicates that the regression predictions fit the data perfectly. The $\mathrm{R}^{2}$ value of this regression model is 0.685 , i. e. $68.5 \%$ of the variation in the SII can be explained by the variation in the PCT patent applications (indicator $\mathrm{X}_{20}$ ).

Tab. 3 - Regression model summary - Slovakia. Source: own processing

\begin{tabular}{|l|l|l|l|l|}
\hline Model & $\mathrm{R}$ & R Square & Adjusted R Square & Std. The error of the Estimate \\
\hline 1 & $.828 \mathrm{a}$ & .685 & .622 & 2.11482 \\
\hline \multicolumn{4}{|l}{ a. Predictors: (Constant), PCT_patent_applications } \\
\hline
\end{tabular}

The p-value (sig.) tests the null hypothesis that the coefficient is equal to zero (no effect), where a low p-value $(<0.05)$ indicates that the null hypothesis can be rejected. The p-value of our regression model is 0.021 , which means that the regression model is statistically significant (Tab. 4).

Tab. 4 - ANOVA ${ }^{\text {b }}$ - Slovakia. Source: own processing

\begin{tabular}{|l|l|l|l|l|l|l|}
\hline \multicolumn{2}{|l|}{ Model } & Sum of Squares & df & Mean Square & F & Sig. \\
\hline 1 & Regression & 48.675 & 1 & 48.675 & 10.883 & $.021 \mathrm{a}$ \\
\hline & Residual & 22.362 & 5 & 4.472 & & \\
\hline & Total & 71.037 & 6 & & & \\
\hline
\end{tabular}

a. Predictors: (Constant), PCT_patent_applications

b. Dependent Variable: SII

The regression output below (Tab. 5) shows that constant and PCT patent applications predictor variables are statistically significant because their $\mathrm{p}$-values are lower than the significance level of 0.05 . Value of constant is 41.354 and coefficient of the predictor (the PCT patent applications) is 0.758 . The regression model of Slovakia is $\mathrm{SII}=0.758 \mathrm{X}_{20}+41.354$. 
Tab. 5 - Coefficientsa ${ }^{-}$Slovakia. Source: own processing

\begin{tabular}{|l|l|l|l|l|l|l|}
\hline \multicolumn{2}{|l|}{ Model } & \multicolumn{2}{|l|}{$\begin{array}{l}\text { Unstandardized } \\
\text { Coefficients }\end{array}$} & $\begin{array}{l}\text { Standardized } \\
\text { Coefficients }\end{array}$ & \multirow{2}{*}{$\mathrm{t}$} & \multirow{2}{*}{ Sig. } \\
\cline { 2 - 5 } & B & Std. Error & Beta & 5.068 & .004 \\
\hline 1 & (Constant) & 41.354 & 8.160 & & 3.299 & .021 \\
\hline $\begin{array}{l}\text { PCT_patent_applica- } \\
\text { tions }\end{array}$ & .758 & .230 & .828 & & \\
\hline
\end{tabular}

\section{Czech Republic}

In the case of the Czech Republic, only one model with one predictor was created. The predictor of the greatest impact on the SII value is Public R\&D expenditure $\left(\mathrm{X}_{9}\right)$. The determination coefficient of the regression model is 0.863 (Tab. 6), which means that $86.3 \%$ of the variation in the SII can be explained by the variation in the Public R\&D expenditures indicator $\left(\mathrm{X}_{9}\right)$. A high coefficient of determination is an indicator of a goodness of the model.

Tab. 6 - Regression model summary - Czech Republic. Source: own processing

\begin{tabular}{|l|l|l|l|l|}
\hline Model & $\mathrm{R}$ & R Square & Adjusted R Square & Std. The error of the Estimate \\
\hline 1 & $.929 \mathrm{a}$ & .863 & .836 & .80179 \\
\hline \multicolumn{4}{|l}{ a. Predictors: (Constant), Public_R_D_expenditure } \\
\hline
\end{tabular}

The p-value (sig.) of the regression model is 0.002 , a result lower than the level of significance (0.05), which means that the regression model is statistically significant (Tab. 7).

Tab. 7 - ANOVA ${ }^{\text {- }}$ - Czech Republic. Source: own processing

\begin{tabular}{|l|l|l|l|l|l|l|}
\hline \multicolumn{2}{|l|}{ Model } & Sum of Squares & df & Mean Square & F & Sig. \\
\hline 1 & Regression & 20.254 & 1 & 20.254 & 31.506 & $.002 \mathrm{a}$ \\
\hline & Residual & 3.214 & 5 & .643 & & \\
\hline & Total & 23.469 & 6 & & & \\
\hline
\end{tabular}

a. Predictors: (Constant), Public_R_D_expenditure

b. Dependent Variable: SII

The regression output below (Tab. 8) shows that the constant and the Public R\&D expenditures predictor variables are statistically significant since their $\mathrm{p}$-values are lower than the significance level of 0.05. The value of the constant is 93.445, and the coefficient of the predictor (the Public $\mathrm{R} \& \mathrm{D}$ expenditures) is -0.072 . The regression model of the Czech Republic is SII $=-0.072 \mathrm{X}_{9}+$ 93.445 . 
Tab. 8 - Coefficients ${ }^{a}$ - Czech Republic. Source: own processing

\begin{tabular}{|l|l|l|l|l|l|l|}
\hline \multirow{2}{*}{ Model } & \multicolumn{2}{|l|}{$\begin{array}{l}\text { Unstandardized } \\
\text { Coefficients }\end{array}$} & $\begin{array}{l}\text { Standardized } \\
\text { Coefficients }\end{array}$ & t & \multirow{2}{*}{ Sig. } \\
\cline { 2 - 5 } & B & Std. Error & Beta & \\
\hline 1 & (Constant) & 93.445 & 1.380 & & 67.695 & .000 \\
\hline & $\begin{array}{l}\text { Public_R_D_ex- } \\
\text { penditure }\end{array}$ & -.072 & .013 & -.929 & -5.613 & .002 \\
\hline
\end{tabular}

\section{Poland}

In the case of Poland, six models were created in the first phase of regression modeling. The first model contained one predictor $\left(\mathrm{X}_{12}\right)$, the second model two predictors $\left(\mathrm{X}_{12}, \mathrm{X}_{13}\right)$, the third model three $\left(\mathrm{X}_{12}, \mathrm{X}_{13}, \mathrm{X}_{9}\right)$, the fourth model contained four $\left(\mathrm{X}_{12}, \mathrm{X}_{13}, \mathrm{X}_{9}, \mathrm{X}_{21}\right)$, the fifth model contained five $\left(\mathrm{X}_{12}, \mathrm{X}_{13}, \mathrm{X}_{9}, \mathrm{X}_{21}, \mathrm{X}_{27}\right)$, with the last model containing six predictors $\left(\mathrm{X}_{12}, \mathrm{X}_{13}, \mathrm{X}_{9}, \mathrm{X}_{21}, \mathrm{X}_{27}\right.$, $\left.\mathrm{X}_{23}\right)$. Only one predictor $\left(\mathrm{X}_{12}\right)$ out of all of them had a high correlation with the SII indicator. The second through the sixth model were excluded, since the predictors (indicators) $\mathrm{X}_{13}, \mathrm{X}_{9}, \mathrm{X}_{21}$, $\mathrm{X}_{27}$, and $\mathrm{X}_{23}$ had a low correlation with the SII.

The predictor of the greatest impact on the SII value was the Non-R\&D innovation expenditure (X12). The determination coefficient of the regression model is 0.724 (Tab. 9), which means that $72.4 \%$ of the variation in the SII can be explained by the variation in the Non-R\&D innovation expenditures indicator $\left(\mathrm{X}_{12}\right)$.

Tab. 9 - Regression model summary - Poland. Source: own processing

\begin{tabular}{|l|l|l|l|l|}
\hline Model & $\mathrm{R}$ & R Square & Adjusted R Square & Std. The error of the Estimate \\
\hline 1 & $.851 \mathrm{a}$ & .724 & .669 & .82790 \\
\hline \multicolumn{4}{|l}{ a. Predictors: (Constant), Non_R_D_innovation_expenditure } \\
\hline
\end{tabular}

The p-value (sig.) of the regression model is 0.015 , a result lower than the level of significance (0.05), which means that the regression model is statistically significant (Tab. 10).

Tab. 10 - ANOVA ${ }^{\text {- }}$ - Poland. Source: own processing

\begin{tabular}{|l|l|l|l|l|l|l|}
\hline \multicolumn{2}{|l|}{ Model } & Sum of Squares & df & Mean Square & F & Sig. \\
\hline 1 & Regression & 9.010 & 1 & 9.010 & 13.146 & $.015 \mathrm{a}$ \\
\hline & Residual & 3.427 & 5 & .685 & & \\
\hline & Total & 12.437 & 6 & & & \\
\hline
\end{tabular}

a. Predictors: (Constant), Non_R_D_innovation_expenditure

b. Dependent Variable: SII

The regression output below (Tab. 11) shows that the constant and the Non-R\&D innovation expenditures predictor variables are statistically significant since their $\mathrm{p}$-values are lower than the significance level of 0.05 . The value of the constant is 41.506 and the coefficient of the pre- 
dictor (the Non-R\&D innovation expenditures) is 0.064 . The regression model of Poland is SII $=0.064 \mathrm{X}_{12}+41.506$.

Tab. 11 - Coefficients ${ }^{\mathrm{a}}$ - Poland. Source: own processing

\begin{tabular}{|l|l|l|l|l|l|l|}
\hline \multicolumn{2}{|l|}{ Model } & \multicolumn{2}{|l|}{$\begin{array}{l}\text { Unstandardized } \\
\text { Coefficients }\end{array}$} & $\begin{array}{l}\text { Standardized } \\
\text { Coefficients }\end{array}$ & \multirow{2}{*}{ t } & \multirow{2}{*}{ Sig. } \\
\cline { 2 - 5 } & B & Std. Error & Beta & & .000 \\
\hline 1 & (Constant) & 41.506 & 3.005 & & 13.811 & .015 \\
\hline & $\begin{array}{l}\text { Non_R_D_innova- } \\
\text { tion_expenditure }\end{array}$ & .064 & .018 & .851 & 3.626 & \\
\hline
\end{tabular}

\section{Hungary}

In the case of Hungary, only one model with one predictor was created. The predictor with the greatest impact on SII value is the Design applications $\left(\mathrm{X}_{22}\right)$. The determination coefficient of the regression model is 0.868 (Tab. 12), which means that $86.8 \%$ of the variation in the SII can be explained by the variation in the Design applications indicator $\left(\mathrm{X}_{22}\right)$. A high coefficient of determination is a positive indicator of the suitableness of the model.

Tab. 12 - Regression model summary - Hungary. Source: own processing

\begin{tabular}{|l|l|l|l|l|}
\hline Model & $\mathrm{R}$ & R Square & Adjusted R Square & Std. The error of the Estimate \\
\hline 1 & $.932 \mathrm{a}$ & .868 & .841 & .84234 \\
\hline
\end{tabular}

The p-value (sig.) of the regression model is 0.002 , a result lower than the level of significance (0.05), which means that the regression model is statistically significant (Tab. 13).

Tab. 13 - ANOVA ${ }^{\text {b }}$ - Hungary. Source: own processing

\begin{tabular}{|l|l|l|l|l|l|l|}
\hline \multicolumn{2}{|l|}{ Model } & Sum of Squares & df & Mean Square & F & Sig. \\
\hline 1 & Regression & 23.281 & 1 & 23.281 & 32.812 & $.002 \mathrm{a}$ \\
\hline & Residual & 3.548 & 5 & .710 & & \\
\hline & Total & 26.829 & 6 & & & \\
\hline
\end{tabular}

a. Predictors: (Constant), Design_applications

b. Dependent Variable: SII

The regression output below (Tab. 14) shows that the constant and the Design applications predictor variables are statistically significant since their $\mathrm{p}$-values are lower than the significance level of 0.05 . The value of the constant is 44.239 , and the coefficient of the predictor (the Design applications) is 1.204. The regression model of Hungary is $\mathrm{SII}=1.204 \mathrm{X}_{22}+44.239$. 
Tab. 14 - Coefficients ${ }^{a}$ - Hungary. Source: own processing

\begin{tabular}{|l|l|l|l|l|l|l|}
\hline \multirow{2}{*}{ Model } & \multicolumn{2}{|l|}{$\begin{array}{l}\text { Unstandardized } \\
\text { Coefficients }\end{array}$} & $\begin{array}{l}\text { Standardized } \\
\text { Coefficients }\end{array}$ & \multirow{2}{*}{ t } & \multirow{2}{*}{ Sig. } \\
\cline { 3 - 5 } & B & Std. Error & Beta & 10.717 & .000 \\
\hline 1 & (Constant) & 44.239 & 4.128 & & 5.728 & .002 \\
\hline & $\begin{array}{l}\text { Non_R_D_innova- } \\
\text { tion_expenditure }\end{array}$ & 1.204 & .210 & .932 & & \\
\hline \multicolumn{2}{|l|}{ a. Dependent Variable: SII } & & & & \\
\hline
\end{tabular}

Four regression models comprise the output of this part of the research. All 27 SII indicators were included in the regression analysis. The aim was to create regression models with each of these indicators included, however, the models were not statistically significant. Therefore, a step-wise regression analysis was applied. With this type of regression modeling, each of the regression models contains only one predictor and one constant. The low number of values (only from 2010 till 2016) caused this problem.

\section{DISCUSSION}

All the Visegrad Group countries belong to the group of moderate innovators, with the summary innovation index values of these countries falling below the EU28 average. The Czech Republic has the best position of all the V4 countries, whereas Poland has the worst. Our findings are quite in line with the opinion of other authors, e.g. Zygmunt (2017), who studied the position of Poland as compared to all of the moderate innovators; and Mikolajczyk (2015), whose research focused on Poland's innovativeness against the background of other EU countries. Slovakia and Hungary reached comparable values for the SII. Moreover, Poland, Slovakia, and Hungary reached the best results within the employment impact category. The Czech Republic showed the best results within the firm investments category. There are several indicators with a high impact on the SII value in each country. There is a wide disparity among the indicators themselves with a high impact on the SII in the countries analyzed. However, some similarity can be seen between Slovakia and the Czech Republic (indicator X27 - Sales of new-to-market and New-to-firm innovations), as well as between the Czech Republic and Hungary (indicator X2 - Population completed tertiary education, X14 - SMEs with product or process innovations, X16 - SMEs innovating in-house). For successful innovation development of the economy in every country, it is necessary to establish certain assumptions that should ensure positive results. Our recommendations match those of Fabova \& Janakova (2015): i) human resources - a qualified, educated and creative workforce; ii) an appropriate research system - a competitive scientific research base which can be involved in international cooperation; iii) the availability of financing for innovation projects along with the promotion of innovation by the government.

Measuring the innovative performance of countries has some limitations, which are also mentioned in Roszko-Wojtowicz \& Bialek (2016). Research on innovativeness continually arouses many controversies and disagreements among examiners. The lively discussion in the field has encouraged authors to express their own views on a multi-dimensional assessment of innovative- 
ness on the basis of the partial indicators included in the Summary Innovation Index. It must be added that research into a particular country's innovativeness is a complex issue. The year 2010 brought significant changes in measuring innovativeness on the European level. The European Innovation Scoreboard (EIS) was revised following the adoption of the Innovation Union Communication (European Commission, 2010). Based on one decade of experience along with the critical opinions regarding previous methodology, a set of modified innovativeness indices in the form of the Innovation Union Scoreboard (IUS) was implemented (Roszko-Wojtowicz \& Bialek, 2016).

\section{CONCLUSION}

Innovation is a prerequisite for competitiveness and economic growth, with several ways to measure and evaluate the innovation performance of a country being possible. Our research focused on the summary innovation index (SII), the most commonly employed indicator for analyzing the innovative ability of European countries. The aim of this paper was to analyze the impact of the SII indicators in terms of the total value of the SII using samples from the V4 countries. Research was divided into three main steps: i) evaluation of the trends of the SII in V4 countries, and a subsequent comparison with the EU average; ii) identification of the indicators with the greatest impact on the SII value, and iii) identification of the main predictors explaining the SII trend. Slovakia and Hungary reached comparable values for the SII. Employment impact is the dominant area for Poland, Slovakia, and Hungary. The dominant area for the Czech Republic concerns firm investments. Several indicators with a high impact on the SII value in each country can be described, with a wide disparity among the indicators with a high impact on the SII in the countries analyzed. Nevertheless, some similarities can be seen between Slovakia and the Czech Republic, as well as between the Czech Republic and Hungary. The latter part of the paper describes four regression models, one for each country. There are no data available for a longer period, which is the deficiency in this analysis. Therefore, each regression model contains only one predictor and constant. With regard to the lack of input variables (27), this deficiency can be eliminated only when more measurements are available in the future. We assume that the reliability of these results will increase from year to year as this research continues. In the last part of the paper, a number of recommendations for improving the innovation performance of the countries are mentioned. Each country should be aware of its strengths and weaknesses in this area and take actions to improve performance.

\section{References}

1. Albulescu, C. T., \& Draghici, A. (2016). Entrerpreneurial activity and national innovative capacity in selected European countries. The international Journal of Entrepreneurship and Innovation, 17 (3), 155-172. https://doi.org/10.1177/1465750316655902

2. Bavec, C. (2009). On the creative climate and innovativeness at the country level. Zbornike Radova Ekonomomskog Fakulteta u Rijeci, 27 (1), 9-29.

3. Cygler, J., \& Sroka, W. (2017). Competition Disadvantages: The Case of the High Tech Companies. Inqinerine Ekonomika-Engineering Economics, 28 (5), 494-504. 
4. Fabova, L., \& Janakova, H. (2015). Impact of the Business Environment on Development of Innovation in Slovak Republic. Proceedings of the International scientific conference: Business Economics and Management (BEM 2015), 34, 66-72, https://doi.org/10.1016/S22125671(15)01602-0

5. Fanelli, V., \& Ryden, A. K. (2018). Pricing a Swing Contract in a Gas Sale Company. Economics, Management, and Financial Markets, 13 (2), 40-55.

6. Gorb, O. (2017). Development of complex approach to defining the notion "sustainable development of rural territories. Forum Scientiae Oeconomia, 5 (2), 87-99.

7. Hraskova, D. (2012). Inovácie- accelerátor prosperity podnikov na Slovensku, Produktivita a Inovácie, 13 (4), 16-17.

8. Kasych, A., \& Vochozka, M. (2017). Theoretical and methodical principles of managing enterprise sustainable development. Marketing and Management of Innovations, 2 (1), 298-305.

9. Kliestik, T., Misankova, M., Valaskova, K., \& Svabova, L. (2018). Bankruptcy Prevention: New Effort to Reflect on Legal and Social Changes. Science and Engineering Ethics, 24 (2), 791-803.

10. Kliestikova, J., Misankova, M., \& Kliestik, T. (2017). Bankruptcy in Slovakia: international comparison of the creditor's position. Oeconomia Copernicana, 8 (2), 221-237.

11. Kyzenko, O., Hrebeshkova, O., \& Grebeshkov, O. (2017). Business intelligence in the economic management of organization. Forum Scientiae Oeconomia, 5 (2), 15-27.

12. Lazaroiu, G., \& Rommer, D. (2017). Digital technologies, labor markets, and economic reputation. Ekonomicko-manazerske spektrum, 11 (2), 13-21.

13. Majerova, I. (2015). Interactions between competitiveness and innovation in selected countries of the European Union and Switzerland. Proceedings of the 12th International Scientific Conference: Economic Policy in the European Union Member Countries. Ostravice, Czech Republic, 540-549.

14. Mece, M. H. (2017). Living in Uncertainty: Resurgence of Blood Feud in Albanian PostSocialist Society and Its Consequences on Children and Young Adults. Contemporary Readings in Law and Social Justice, 9 (2), 28-38.

15. Mikolajczyk, B. (2015). Poland's Innovativeness Against the Background of EU

Countries (recent research results). Comparative Economic Research, 18 (2), 21-35, https://doi. org/10.1515/cer-2015-0010

16. Misankova, M., \& Chlebikova, D. (2013). Possibilities for financing innovation activities in Slovak Republic.Proceedings of 9th International Scientific Conference on Financial Management of Firms and Financial Institutions. Ostrava, Czech Republic, 562-570.

17. Moravcikova, D., Krizanova, A., Kliestikova, J., \& Rypakova, M. (2017). Green marketing as the source of the competitive advantage of the business. Sustainability, 9 (12), art.no. 2218.

18. Nica, E., Comanescu, M., \& Manole, C. (2017). Digital Reputation and Economic Trust in the Knowledge Labor Market. Journal of Self-Governance and Management Economics, 5 (3), $83-88$. 
19. Oslikova, E., Ticha, A., \& Bartos, M. (2015). Technical Product Innovation in Building Material Industry in the Czech Republic. Procedia Computer Science, 64, 691-696. https://doi. $\operatorname{org} / 10.1016 /$ j.procs.2015.08.586

20. Ostraszewska, Z., \& Tylec, A. (2016). Polish economy innovation on the background of the European Union and research\&development activity financing in 2008 - 2014. Proceedings of the 21st International Scientific Conference on Smart and Efficient Economy - Preparation for the Future Innovative Economy, 595-602.

21. Paliderova, M., \& Hraskova, D. (2016). Dimension of innovation in enterprises. Proceedings of the 16th international scientific conference Globalization and its socio-economic consequences, 1613-1619.

22. Popescu L. D. (2017). Global Policy Mechanisms, Intergovernmental Power Politics, and Democratic Decision-Making Modes of Transnational Public Administration. Geopolitics, History, and International Relations, 9 (2), 199-205.

23. Popp, J., Kot, S., Lakner, Z., \& Olah J. (2018), Biofuel use: Peculiarities and implications. Journal of Security and Sustainability Issues, 7 (3), 477-493.

24. Regnerova, O., \& Regnerova, M. (2017). Sustainable development in "the light and shadow" of globalization. Ekonomicko-manazerske spektrum, 11 (1), 2-12.

25. Roszko-Wojtowicz, E., \& Bialek, J. (2016). A multivariate approach in measuring innovation performance. Proceedings of Rijeka Faculty of Economics, 34 (2), 443-479, https://doi. org/10.18045/zbefri.2016.2.443

26. Rylkova, Z. (2016). Innovation performance of the Czech Republic and international benchmarking. Proceedings of the 14th International Scientific Conference: Economic Policy in the European Union Member Countries. Petrovice Karvine, Czech Republic, 610-618.

27. Sadaf, R., Olah, J., Popp, J., \& Mate, D. (2018). An investigation of the influence of the worldwide governance and competitiveness on accounting fraud cases: A cross-country perspective. Sustainability, 10, ar. no: 588

28. Scholleova, H. (2009). Czech Republic innovations evaluated by summary innovation index. Proceedings of the International Scientific Conference on Hradec Economical Days 2009 - Economic Development and Management of the Region, 203-210.

29. Sipos, G. L., Bizoi, G., \& Ionescu, A. (2014). The Impact of Hampering Innovation Factors on Innovation Performance - European Countries Case. Challenges and Innovations in Management and Leadership. Procedia - Social and Behavioral Sciences, 124, 415-424. https://doi.org/10.1016/j.sbspro.2014.02.503

30. Stoian, M. M., \& Nica, A. M. (2016). Innovation Progress at International Level. The European Proceedings of Social \& Behavioural Sciences, 15, 957-964. https://doi.org/ 10.15405/ epsbs.2016.09.119

31. Stonkute, E., Vveinhardt, J., \& Sroka, W. (2018). Training the CSR Sensitive Mind-Set: The Integration of CSR into the Training of Business Administration Professionals. Sustainability, 10 (3), art. no. 754

32. Svagzdiene, B., \& Kuklyte, J. (2016). The analysis of factors which have impact for 
summary innovation index in Germany, Estonia and Lithuania. Transformations in Business \& Economics, 15 (2B), 784-799.

33. Vojtovic, S. (2016). The Impact of the Structural Funds on Competitiveness of Small and Medium-Sized Enterprises. Journal of Competitiveness, 8 (4), 30-45.

34. Wierzbicka, W. (2018). Information infrastructure as a pillar of the knowledge-based economy - an analysis of regional differentiation in Poland. Equilibrium Quarterly Journal of Economics and Economic Policy, 13 (1), 123-139. https://doi.org/10.24136/eq.2018.007

35. Zelazny, R., \& Pietrucha, J. (2017). Measuring innovation and institution: the creativity economy index. Equilibrium Quarterly Journal of Economics and Economic Policy, 12 (1), 43-62. https://doi.org/10.24136/eq.v12i1.3

36. Zygmunt, A. (2017). Innovation activities of Polish firms. Multivariate analysis of the moderate innovator countries. Oeconomia Copernicana, 8 (4), 505-521. https://doi. org/10.24136/oc.v8i4.31

\section{Contact information}

Ing. Janoskova Katarina, PhD.

University of Zilina

The Faculty of Operation and Economics of Transport and Communications

Department of Economics

Slovak Republic

E-mail: katarina.janoskova@,fpedas.uniza.sk

ORCID: 0000-0002-7887-7326

doc. Ing. Kral Pavol, PhD.

University of Zilina

The Faculty of Operation and Economics of Transport and Communications

Department of Economics

Slovak Republic

E-mail:pavol.kral@fpedas.uniza.sk

ORCID: 0000-0001-6970-563 